\title{
ObSERVATIONS ON LYCAENID BUTterfles fROM PANBARI RESERVE FOREST AND ADJOINING AREAS, KAZIRANGA, ASSAM, NORTHEASTERN INDIA
}

\section{Monsoon Jyoti Gogoi}

Ph.D Student, Department of Ecology \& Environmental Science, Assam University, Silchar, Assam 788011, India monsoonjyoti@gmail.com

Abstract: A checklist of 116 taxa of Lycaenidae (Blues) along with notes on important species in low elevation forest of Panbari Reserve, Kaziranga - West Karbi Hills, upper Assam is reported in this paper based on surveys conducted during 2007-2012 and some recent sightings till date. Important sightings include Blue Gem Poritia erycinoides elsiei, Square-band Brownie Miletis nymphys porus, Plain Plushblue Flos apidanus ahamus, Blue Royal Ancema carmentalis, Elwes Silverline Spindasis elwesi, Artipe skinneri, etc.

Keywords: Butterfly diversity, Kaziranga, Lycaenidae, northeastern India, Panbari Reserve.

The Lycaenidae (Blues) butterfly diversity in low elevation forests of Panbari Reserve, Kaziranga - West Karbi Hills, upper Assam is reported in this paper. Karbi Hills constitue a chain of hill ranges lying in middle Assam in the southern bank of the river Brahmaputra. Karbi Hills are totally data deficient as no previous work is known from this area as most of the earlier extensive work has been conducted in its neighbouring hills - Cachar Hills (Wood-Mason and De Nice'ville 1887), Khasi, Jaintia Hills (Cantlie 1952) and some from Margherita, Sivasagar, Jorhat and Nambor, Assam (Norman 1953). The area lacks altitudinal gradient and hence the diversity is likely to be less here. The area, however, is very rich in skippers (Gogoi 2013). In this study, an attempt has been made to document the Lycaenidae of Kaziranga-Karbi Hills

\section{MethodS \\ Study area}

The Panbari Reserve Forest $\left(26^{\circ} 36^{\prime} \mathrm{N} \& 93^{\circ} 30^{\prime} \mathrm{E}\right)$ is protected under the Kaziranga National Park (KNP) as its fourth addition (Images $1 a, b \& 2$ ). The average elevation of the forest is around $90 \mathrm{~m}$. The altitude however ranges from $\mathbf{7 0 - 3 0 0 ~} \mathrm{m}$. The reserve is very close to National Highway 37 (NH37) on the GuwahatiJorhat route. The reserve falls between Golaghat and Karb Anglong (KA) districts of Assam. To the north of the reserve lies Dollamora proposed reserve in Karbi Anglong District and on the southern boundary is a human settlement. To its west lies NH47 and grasslands of KNP and to its east lies Karbi Village. Only $7 \mathrm{~km}^{2}$ of the area is under KNP and the rest is under KA. The reserve is one of the last remaining natural stretches of undisturbed semi-evergreen forest in the area. The northern part, Dollamora, is being degraded to some extent due to human interference.

Sampling of butterflies was carried throughout the year from 2007-2012. Species were identified on the basis of identification keys and photographs from Evans

DOI: http://dx.doi.org/10.11609/jott.2467.7.15.8259-8171 | ZooBank: urn:Isid:zoobank.org:pub:8FD12D64-0A85-4D8F-9976-D15CAEDC136B

Manuscript details: Ms \# 03687 | Received 02 July 2013 | Final received 30 November 2015 | Finally accepted 09 December 2015

Citation: Gogoi, M.J. (2015). Observations on lycaenid butterflies from Panbari Reserve Forest and adjoining areas, Kaziranga, Assam, northeastern India. Journal of Threatened Taxa 7(15): 8259-8271; http://dx.doi.org/10.11609/jott.2467.7.15.8259-8171

Copyright: (C) Gogoi 2015. Creative Commons Attribution 4.0 International License. JoTT allows unrestricted use of this article in any medium, reproduction and distribution by providing adequate credit to the authors and the source of publication.

Funding: None.

Conflict of Interest: The author declares no competing interests.

Acknowledgements: I thank Gaurab Nandi Das, Bitupon Boruah and Raju Kasambe for sharing their sightings. I also thank WWF-KKL and Garga Mohan Das, Tapan Das, Arif Hussain, Phalgun Chetia, Abidur Rahman and many others for assisting me in the field. I also thank Rabin Sarma, research officer of KNP, Uttam Saikia and Dr. Manashi Bortamuli. 


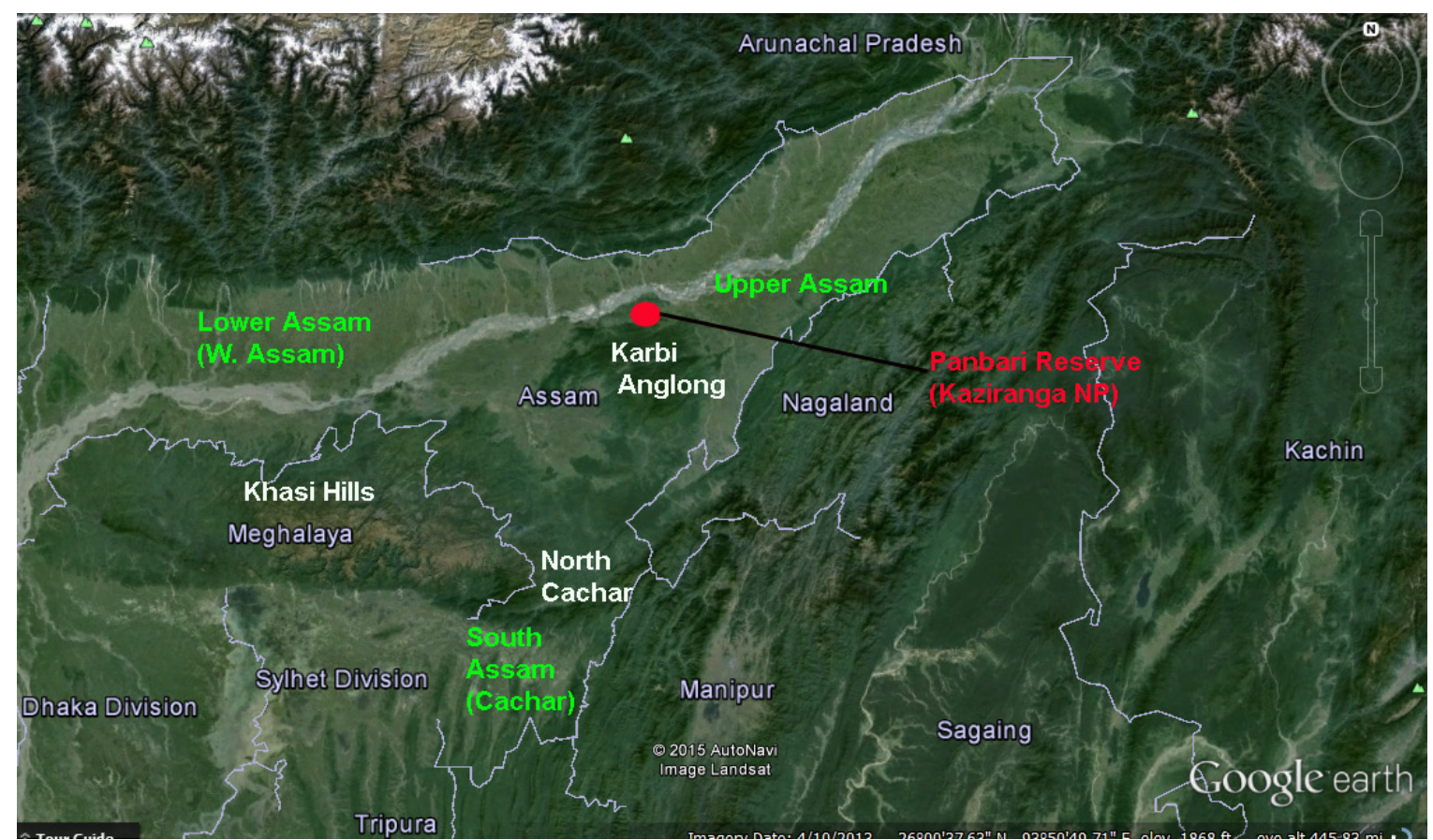

Image 1a. Google map showing location of Panbari Forest in Assam

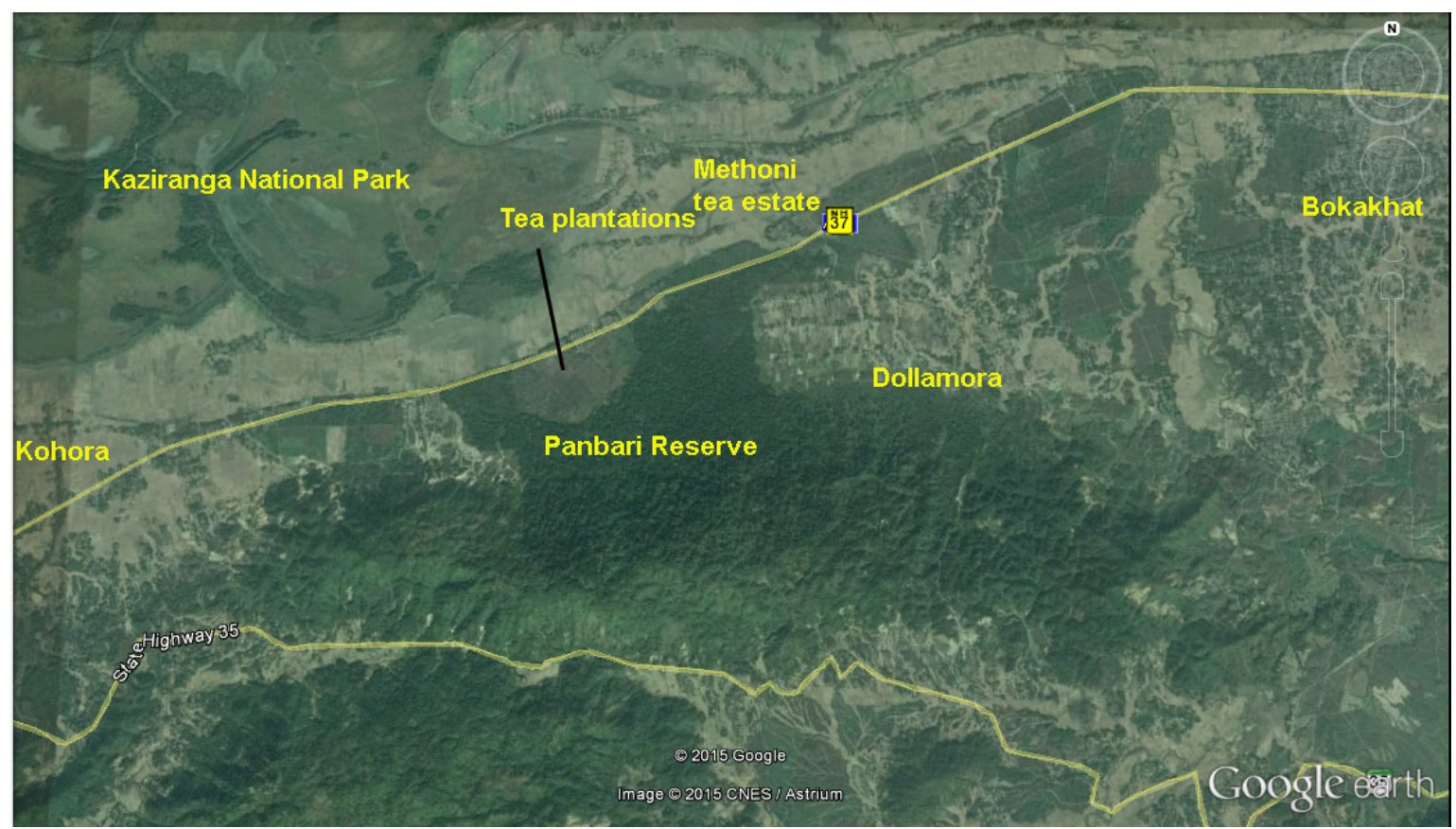

Image 1b. Google map with detail of the study area

(1932), Evans (1957), Haribal (1992), Kehimkar (2008) and a website on butterflies of Indo-China (http:// yutaka.it-n.jp/).

\section{RESULTS}

A total of 116 taxa were recorded in this study
(Table 1). Important sightings include Blue Gem Poritia erycinoides elsiei legally protected under Schedule II, Square-band Brownie Miletis nymphys porus (previously Bigg's Brownie Miletus biggsii) protected under Schedule I, Malayan Bushblue Arhopala ammonides protected under Schedule I, Elwes Silverline Spindasis elwesi 


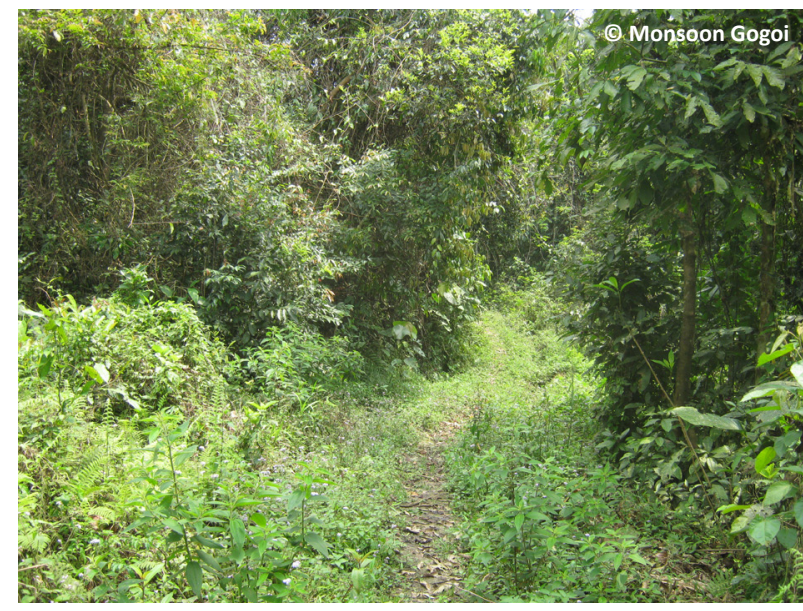

Image 2. A forest trail of Panbari Forest, Kaziranga

legally protected under Schedule I, Artipe skinneri, Plain Plushblue Flos apidanus ahamus, Blue Royal Ancema carmentalis De Nicéville, 1892. and many other rare species. Peacock Oakblue Arhopala horsfieldii appears to be a new record for India. Females of Artipe sp. were always found near the host plant and males near the females and both camouflaged with green leaves. Brief notes on various species recorded in this study are given below.

\section{Subfamily Poritiinae}

Blue Gem Poritia erycinoides elsiei Evans, 1925: The taxon was recorded on many occasions in tea gardens of Panbari and once photographed on 29 December 2008 (Image 3). Several males and four females were reported in Sebong, Manipur and a single male in Saitu, Manipur Valley by Tytler (1915). The species was reported earlier from Khasi Hills as rare (Cantile 1952). It is a lesserknown species from northeastern India.

\section{Subfamily Miletinae}

Common Brownie Miletus chinensis assamensis Doherty, 1891: The taxon was seen a few times in Panbari, first photographed in 20 July 2008 (Image 4) and was reported from Dowki, Khasi Hills as rare (Cantile 1952). It is distributed from Sikkim to Arunachal and northeastern India from low to mid-elevations (Kehimkar 2008).

Common Brownie Miletus boisduvali Moore, 1857: One specimen was encountered on 24 July 2009 in Panbari forest. This could be a form of $M$. chinensis but can easily be distinguished from $M$. chinensis assamensis in having ground colour being white in place of pale grey. There is a lot of confusion regarding this species, as $M$. assamensis was previously placed under Miletus boisduvali. The species is distributed from Sikkim to northeastern India (Evans 1932).

Squareband Brownie Miletus nymphis porus Eliot, 1961: Seen once at Panbari on 09 July 2009 (Image 6). The taxon was confirmed on the basis of a sub-terminal series of black dots and underside pale-brownish grey with a faint pinkish tinge (Swinhoe 1905-1910); reported from Chin Hills and Chin Lushai by Watson, and from Naga and Karen hills by Elwes (Swinhoe 1905-1910). The description of M. biggsii in Evans (1932) is of this taxon. $M$. biggsii is protected under schedule $\mathrm{I}, \mathrm{WL}(\mathrm{P})$ A, 1972 although it actually occurs in Myanmar. Miletus biggsii in the Indian Wildlife Protection Act should be changed to $M$. nymphis porus.

\section{Subfamily Lycaeninae}

Pointed Pierrot Tarucus theophrastus indica Evans, 1932: A common taxon seen in grasslands of Kaziranga and Bokakhat and seen all year round, it shows seasonal variation of wing border and spots of upper side (Images 7-10). It was reported from Baluchistan, Punjab, Kathiawar, Rajputana by Evans (1932) but no report from northeastern India, however, it is common in and around the Brahmaputra River. The taxon was confirmed with Evans (1932), male, since its border of upper side forewing is over $1 \mathrm{~mm}$ and termen straight towards tornus.

Tarucus sp: Seen twice in Panbari (Images 11, 12). These are possibly T. callinara Butler, 1886, female since female of callinara has a spotted white disc forewing (Evans 1932). I keep the species doubtful, examination of the male genitalia is needed for identification of the species, due to seasonal and geographic variability (Evans 1932).

White Cerulean Jamides cleodus pura Moore, 1886: A male was sighted once at Panbari on 25 November 2010 (Images 13, 14). In the male of the taxon the border of the upper side of the forewing is not dilated at the apex, which differentiates it from the male of the Common Cerulean Jamides celeno celeno. Females of both taxa are very similar and were not identified as they need dissection of genitalia. Cantile (1952) reported the taxon from the Sylhet side of Khasi Hills but never from the side facing Assam Valley. Cantile mentions both WSF and DSF of the taxon and the fact that in November the WSF disappears. Evans (1932) mentioned DSF, but the specimen I recorded was in the dry season and did not show any seasonal form, at the same time the Common Cerulean Jamides celeno celeno showed seasonal variations (Images 15, 18, 19). I have recorded this taxon 
several times in Cachar Hills during winter (Images 16, 17).

Elwes Silverline Spindasis elwesi Evans, 1925: Encountered around 5-6 times in PF in an open hill stream on the edge of Panbari Forest, Kaziranga. Two photographs obtained on 15 and 22 May 2008 are probably of WSF (Image 25). Another specimen was encountered on 28 March 2008 in the same area as the previous ones where the background is somewhat creamy khaki, instead of white (Image 26). It was found sitting in a small stream, whereas in the former case it was seen above a bush.

Hill Hedge Blue Celastrina agriolus sikkima Moore, 1883: DSF was observed in the month of December (Image 30). The taxon is very like $C$. jynteana but underside markings become obscure in DSF of sikkima, whereas DSF markings are clear in jynteana (Evans 1932).

White-banded Hedge Blue Lycaenopsis transpectus Moore, 1879: The species is very variable in northeastern India, but always has a spot near base 1b (Evans 1932), which is absent in C. argiolus sikkima and jynteana (Image 31). The male of this species recorded in Panbari were bright, shining blue with a border of $2 \mathrm{~mm}$ mentioned in Evans (1932), but I found that sometimes the border is narrow in Cachar races (Image 32). In females, the hind wing is white in DSF (Image 33).

Plain Plushblue Flos apidanus ahamus Doherty, 1891: Encountered once in PF on 24 |October 2010 (Image 36). The species is smaller in size than other Plushblues. The subspecies first described from upper Assam is known from Assam, Chittagong, Bhamo, Karens, Atran, Tavoy, Siam, Sumatra (Evans 1957).

Bifid Plushblue Flos diardi diardi Hewitson, 1862: Encountered four times in PF (Image 37). One male twice in the same area and two females were encountered. The taxon was also sighted once from Kohora range in KNP. The subspecies is distributed from Sikkim-Assamnothern Myanmar to Mergui (Evans 1957). The taxon is known from six males and a female and a pair in the low hills between Cherra and Dowki and was rare (Cantile 1952).

Malayan Bushblue Arhopala ammonides elira Corbet, 1941: Sighted once in PF. The taxon was sighted a few times in nearby Dollamora PRF (Image 38). One specimen was also encountered by Gaurab Nandi Das (pers. comm. 2012) in Bokakhat Town. I personally encountered the taxon many times in Cachar Hills during February-March 2012-2015 (unpublished data 2015). The Khasi Hills specimens having a white patch in space seven of the underside hind wing by Corbet was given a new name $A$. ammonides elira instead of $A$. ammon ariel described from Margherita, upper Assam, lacking the white patch (Cantile 1952). It appears that the taxon is restricted to Meghalaya-Karbi-Cachar complex of northeastern India.

Sylhet Oakblue Arhopala silhetensis Hewitson, 1862: Two specimens that were encountered were very large in comparison to the specimen encountered in Jeypore Reserve and Cachar Hills (Image 30). However, small specimens were also seen. The species is seen in wing in extreme summer when other Arhopala gradually disappear in low elevations. The species was reported from Naga Hills and Sebong, Manipur as rare (Tytler 1915b).

Green Oakblue sp. Arhopala hellenore hellenore Doherty, 1889: Seen twice in a hill stream of Panbari on 25 March 2009, this is a rare Oakblue (Image 40). It was, however, reported common at Imphal, Sebong and Cachar road, Manipur (Tytler 1915b). The taxon is reported from Assam, Chittagong, Burma, Cambodia, Siam, Hainan, Java (Evans 1957).

Peacock Oakblue Arhopala horsfieldii eurysthenes Fruhstorfer, 1914: The taxon has a green upper side, first sighted in 22 September 2007, and is not rare at Panbari (Image 41). The subspecies is reported from Tenasserim, Karens, Ataran, Mergui, Victoria Point, Peninsular Siam, Langkawai Island (Evans 1957). It appears that the taxon is not reported from India earlier, hence making this the first record for the country.

Vinous Oakblue Arhopala athada apha De Nicéville 1895: The taxon was sighted once in Panbari in April 2009, however, it could be seen a few times in the woodlands of Bokakhat Anadapur tea estate and I succeeded in photographing it in July 2009 (Image 42). The subspecies is reported from Martaban of Burma, Assam, Northern Shan States, Ataran, Tavoy, Mergui, Victoria Point, southern Burma (Evans 1957).

Arhopala sp.: This resembles Arhopala nicevillei (Bethune-Baker 1903) as in the forewing the discal band is broken or sinuous at v4 (Evans 1957). However, in the specimen, the spot in space 6 is not larger than in 5 for Arhopala nicevillei (Evans 1957). Sighted on 12 July ¡2009.

Arhopala sp.: The taxon is probably Arhopala zambra zambra (Swinhoe 1910) as it matches the description of Evans (1957). It was seen once on 02 March 2009 (Image 43). The tornus is very elongated (more than $A$. silhetensis). The size is very large in comparison to other Oakblues.

Spotless Oakblue Arhopala fulla ignara Riley \& Godfrey, 1921: It was commonly observed in Panbari 
from 09 June 2008 to 28 September 2008 and in subsequent years seen from 10 April 2010 (Image 44). The taxon was however treated rare in distribution from Sikkim to Myanmar (Evans 1932).

Silky Oakblue Arhopala alax Evans, 1932: The species was seen twice in Panbari, once on 18 June 2008 (Image 45) and again on 29 April 2010. It was seen on both occasions in the starting patches of the forest near NH37. The species has been reported from Manipur, northern Myanmar, Northern Shan States, Southern Shan States, Karens, Ataran and western Siam but not so far from upper Assam. This is the first record of the species in Assam (Evans 1957).

Powdered Oakblue Arhopala bazalus teesta de Nicéville, 1886: The taxon was seen more than 10 times at Panbari from 22 May 2009 to 24 July 2009; one female and the rest males (Images 46,47 ). The female lacks the powdered glaze of the male. It was not rare (Evans 1932).

Branded Yamfly Yasoda tripunctata Hewitson, 1863: The species was sighted first in Panbari in May 2010 (Image 49). I saw the species 30 times after this during April-May. Locally very common in Panbari, however, it was never sighted in 2008 and 2009 and hence, the sudden increase in population was really surprising. The species was rare in Meghalaya, one sighting from Dowki by Cantile in July after a long search by him and one record by Swinhoe from Khasi Hills (Cantile 1952).

Common Onyx Horaga onyx onyx Moore, 1857: Seen a few times in winter during 30 December 2007 and 01 January 2008 at Panbari forest, Kaziranga (Image 50). Females are yellower in colour and were recorded in October 2009. Most of the time I encountered males, while a female was recorded only once.

Suffused Flash Rapala suffusa Moore, 1878: The species was sighted only once sitting on a leaf in Panbari on 13 July 2009 (Image 51). It was reported as common in Manipur (Tyler 1915b). Its similar to Rapala tara but the former is smaller in size and appears to occur in lower elevations than the latter.

Green Flash Artipe eryx Linnaeus, 1771: Seen a few times, in Panbari Reserve, both male and female during 08 August 2008 and 20 May 2009, and in Numaligarh Reserve on 21 November 2007 (Images 53, 54). The species is always seen near green leaves and females are always found near the host plant (Catunaregum sp. of Rubiaceae). The females were recorded laying eggs on seeds. The species was not uncommon in Manipur Valley (Tytler 1915b). It was very rare in Meghalaya and only one female was reported from Cherra (Cantile 1952).

Cachar Flash Artipe skinneri De Nicéville, 1887: One individual was encountered in Dollamora forest adjoining Panbari on 18 April 2010 (Image 55). The species was reported from Cachar (the type locality) (Wood-Mason \& De Nice'ville 1886) and from Imphal, Manipur (Tytler 1915b). Tytler (1915b) presumed it to be a DSF of $A$. eryx and hence Evans (1932) treated it as a variation of eryx. The species, however, was encountered in mid-April and hence cannot be a DSF.

Malayan Red Flash Rapala damona Swinhoe, 1890: The species was seen commonly in degraded patches of Panbari on 31 October 2008 (Images 56-58). The species could also be seen sometimes in the villages and town of Bokakhat and degraded patches of Dollamora. One individual was photographed at my home, at Bokakhat on 27 August 2007. Interestingly, the species has not been reported from the northern bank of the Brahmaputra.

Witch Araotes lapithis Moore 1857: Not rare in Panbari during May and found locally, common in some locations of Dollamora during November (Image 62). However, the species was treated as rare (Evans 1932). The species was known from a single male at Nichuguard, Naga Hills and another at Sebong, Manipur (Tytler 1915).

Narrow Spark Sinthusa nasaka amba Kirby, 1878: Seen many times in Panbari it is not rare in Panbari in some seasons (Image 61). Six males and seven females were collected from western Manipur Hills and from Sebong (Tytler 1915). The species was reported as being very rare in Khasi hills (Cantile 1952). It appears that the species is more common in lower elevations.

Blue Royal Ancema carmentalis De Nicéville, 1892: Encountered once at PF on 29 May 2009, the species was described from Khasi Hills (Image 64). Earlier placed under $A$. icetoides (Karens, southern Burma) it occurs in Assam and was not rare (Evans 1932).

\section{Subfamily Curetinae}

Burmese Sunbeam Curetis saronis gloriosa Moore, 1883: One individual was seen in the Kohora range of Kaziranga in April 17,2008 and a female in September 2009 (Images 67, 68). The taxon was reported from the plains below Cherra and Dowki, Meghalaya and Nowgong Town, Central Assam (Cantile 1952). It was also reported from Cachar (Wood-Mason \& De Nice'ville 1886). The species is also reported from Tongla, western Assam (D. Moholia pers. comm. 2010).

\section{DISCUSSION AND CONCLUSION}

Forested areas in the lower elevations of upper Assam especially western Karbi Hills are undergoing 
Table 1. A preliminary checklist of Lycaenidae recorded in Panbari forest of Kaziranga and neighbouring areas of Karbi Hills (2008-2012)

\begin{tabular}{|c|c|c|c|c|}
\hline & Common name & Scientific name & WLPA 1972 & Comments \\
\hline 1 & Blue Gem & Poritia erycinoides elsiei Evans, 1925 & Schedule II & Seen in tea gardens of Panbari \\
\hline 2 & Common Gem & Poritia hewitsoni Moore, 1865 & Schedule II & Seen in Panbari \\
\hline 3 & Common Brownie & Miletus chinensis assamensis Doherty, 1891 & & Seen few times trails by the forest edges \\
\hline 4 & Common Brownie & Miletus boisduvali Moore, 1857 & & Seen a few times at Panbari \\
\hline 5 & Square-band Brownie & Miletus nymphis Fruhstorfer, 1913 & Schedule I & Seen once in a trail by forest edge \\
\hline 6 & Elbowed Pierrot & Pycnophallium elna Hewitson, 1876 & & Seen commonly in hill streams \\
\hline 7 & Banded-blue Pierrot & Discolampa ethion Westwood, 1851 & & Seen only once \\
\hline 8 & Common Pierrot & Castalius rosimon Fabricius, 1775 & & Abundant everywhere \\
\hline 9 & Pointed Pierrot & Tarucus theophrastus indica Evans, 1932 & & Seen in degraded and open areas \\
\hline 10 & Spotted Pierrot & Tarucus callinara Butler, 1886 ? & & $\begin{array}{l}\text { Seen a few times in the open spaces of foothills. } \\
\text { The identity of the species is doubtful and the } \\
\text { genitalia needed to be examined. }\end{array}$ \\
\hline 11 & Zebra Blue & Leptotes plinius Fabricius, 1793 & & Common species \\
\hline 12 & Forest Quaker & Pithecops hylax Horsfield, 1828 & & Seen many times inside Panbari \\
\hline 13 & Forest Quaker & Pithecops corvus Fruhstorfer, 1919 & & Seen many times inside Panbari \\
\hline 14 & Quaker & Neopithecops zalmora Butler, 1870 & & Very often seen mud-puddling in damp patches \\
\hline 15 & Malayan & Megisba malaya Horsfield, 1828 & & Common in panbari,seen very often in streams \\
\hline 16 & Common Hedge Blue & Acytolepis puspa Horsfield, 1828 & & Seen everywhere \\
\hline 17 & $\begin{array}{l}\text { White-banded Hedge } \\
\text { Blue }\end{array}$ & Lycaenopsis transpectus Moore, 1879 & & Seen in winter \\
\hline 18 & Plain Hedge blue & Celastrina lavendularis limbata Moore, 1879 & & Seen in summer, winer \\
\hline 19 & Pale Hedge Blue & Udara dilecta Moore, 1879 & & Seen in winter \\
\hline 20 & Hill Hedge Blue & Celasteina argiolus sikkima Moore, 1883 & & DSF observed in winter \\
\hline 21 & Lime Blue & Chilades laius Cramer, 1782 & & Seen everywhere \\
\hline 22 & Pale Grass Blue & Pseudozizeeria maha Kollar, 1848 & & Seen everywhere \\
\hline 23 & Lesser Grass Blue & Zizeeria otis Fabricius, 1787 & & Seen everywhere \\
\hline 24 & Dark Grass Blue & Zizeeria karsandra Moore, 1865 & & Common everywhere \\
\hline 25 & Indian Cupid & Everes lacturnus assamica Tytler, 1915 & & Seen once by Gaurab Nandi Das in Bokakhat \\
\hline 26 & Gram Blue & Euchrysops cnejus Fabricius, 1798 & & Common in Kaziranga \\
\hline 27 & Ciliate Blue & Anthene emolus Godart, 1823 & & Very often seen forest edges \\
\hline 28 & Pointed Ciliate Blue & Anthene lycaenina C. Felder, 1868 & Schedule II & Seen commonly at forest edges \\
\hline 29 & Forget me not & Catachrysops strabo Fabricius, 1793 & & Seen in open spaces by forest \\
\hline 30 & Silver Forgetmenot & Catachrysops lithargyria Doherty, 1891 & & Uncommon in Panbari \\
\hline 31 & Peablue & Lampides boeticus Linnaeus, 1767 & Schedule II & Seen in open places and degraded areas in winter \\
\hline 32 & Glistening Cerulean & Jamides elpis Godart, 1824 & & Common \\
\hline 33 & Dark Cerulean & Lampides bochus Cramer, 1782 & & Seen in human habitats too \\
\hline 34 & Common Cerulean & Jamides celeno Cramer, 1775 & & Common \\
\hline 35 & White Cerulean & Jamides cleodus pura Moore, 1886 & Schedule II & Seen twice in the hill streams of Panbari \\
\hline 36 & Metallic Cerulean & Jamides alecto Felder, 1860 & & Common \\
\hline 37 & Royal Cerulean & Jamides caerulea Druce, 1873 & & Rare, seen at Panbari \\
\hline 38 & Large 4 Lineblue & $\begin{array}{l}\text { Nacaduba pactolus continentalis Fruhstorfer, } \\
1916\end{array}$ & Schedule II & Not rare \\
\hline 39 & Pale Four-line Blue & Nacaduba hermus Felder, 1860 & Schedule II & Seen many times \\
\hline 40 & Violet 4 Lineblue & Nacaduba pavana vajuva Fruhstorfer, 1916 & & Seen a few times \\
\hline 41 & Small 4 Lineblue & Nacaduba pavana pavana Horsfield, 1828 & & Seen a few times \\
\hline 42 & Pointed Lineblue & Ionolyce helicon merguiana Moore, 1884 & Schedule II & Seen few times \\
\hline
\end{tabular}




\begin{tabular}{|c|c|c|c|c|}
\hline & Common name & Scientific name & WLPA 1972 & Comments \\
\hline 43 & Transparent Six-line Blue & Nacaduba kurava Moore, 1857 & & Common in some patches \\
\hline 44 & Opague 6 Lineblue & Nacaduba beroe gythion Fruhstorfer, 1916 & & Seen in wooldlands of Bokakhat \\
\hline 45 & Common Lineblue & Prosotas nora ardates Moore, 1874 & & Common \\
\hline 46 & Banded Lineblue & Prosotas lutea Martin, 1895 & & Rare \\
\hline 47 & Tailless Lineblue & Prosotas dubiosa indica Evans, 1925 & & Common \\
\hline 48 & Dingy Lineblue & Petrelaea dana de Nicéville, 1883 & & Common \\
\hline 49 & Purple Sapphire & Heliophorus epicles indicus Fruhstorfer, 1908 & & Common \\
\hline 50 & Angled Sunbeam & Curetis dentata dentata Moore, 1879 & & Common \\
\hline 51 & Bright Sunbeam & Curetis bulis Westwood, 1851 & & One seen at Panbari \\
\hline 52 & Burmese Sunbeam & Curetis saronis gloriosa Moore, 1883 & & One seen at Kohora \\
\hline 53 & Silverstreak Blue & Iraota timoleon Stoll, 1790 & & One seen at Bokakhat \\
\hline 54 & Sylhet Oakble & Arhopala silhetensis Hewitson, 1862 & Schedule II & Seen few times \\
\hline 55 & Zambra Oakblue & Arhopala zambra zambra Swinhoe 1910 ? & & Seen once at Panbari \\
\hline 56 & Indian Oakblue & Arhopala atrax Hewitson, 1862 & & Seen many times in winter \\
\hline 57 & Silky Oakblue & Arhopala alax Evans, 1932 & & Seen in the starting forest patches of Panbari \\
\hline 58 & Vinous Oakblue & Arhopala athada apha De Nicéville, 1895 & & Seen at Bokakhat, Panbari \\
\hline 59 & Large-spotted Oakblue & Arhopala nicevillei Bethune-Baker, 1903? & & Seen once in a hill stream of Panbari \\
\hline 60 & Powdered Oakblue & Arhopala bazalus teesta De Niceville, 1886 & & Seen more than 10 times at Panbari \\
\hline 61 & Tamil Oakblue & Arhopala bazaloides Hewitson, 1878 & Schedule II & $\begin{array}{l}\text { One seen by Bitupon Das in Kohora (pers. Comm. } \\
\text { 2012) }\end{array}$ \\
\hline 62 & Green Oakblue & Arhopala eumolphus Cramer, 1782 & & Seen at Panbari \\
\hline 63 & Peacock Oakblue & $\begin{array}{l}\text { Arhopala horsfieldi eurysthenes Fruhstorfer, } \\
1914\end{array}$ & & Seen at Panbari \\
\hline 64 & Green Oakblue & Arhopala hellenore Doherty, 1889 & & Seen a few times in the hill streams of Panbari \\
\hline 65 & Centaur Oakblue & Arhopala centaurus pirithous Moore, 1883 & & $\begin{array}{l}\text { Most common Oakblue species, also seen in } \\
\text { woodlands of Bokakhat }\end{array}$ \\
\hline 66 & Spotless Oakblue & Arhopala fulla ignara Riley \& Godfrey, 1921 & Schedule II & Common in Panbari \\
\hline 67 & $\begin{array}{l}\text { Yellowdisc Tailless } \\
\text { Oakblue }\end{array}$ & Arhopala perimuta Moore, 1857 & & Common in Panbari, Dollamora \\
\hline 68 & Hooked Oakblue & Arhopala paramuta de Nicéville, 1883 & & Not rare \\
\hline 69 & Malayan Bushblue & Arhopala ammonides elira Corbet, 1941 & Schedule I & Seen at Panbari,Dollamora \\
\hline 70 & Aberrant Oakblue & Arhopala abseus indicus Riley, 1923 & & Seen once at Panbari \\
\hline 71 & Bifid Pushblue & Flos diardi diardi Hewitson, 1862 & & $\begin{array}{l}\text { Seen few times at Panbari, also seen by Bitupon } \\
\text { Borua at Kohora }\end{array}$ \\
\hline 72 & Plain Plushblue & Flos apidanus ahamus Doherty, 1891 & & Seen once at Panbari \\
\hline 73 & Common Acacia Blue & Surendra quercetorum Moore, 1857 & & Common \\
\hline 74 & Yamfly & Loxura atymnus Cramer, 1782 & & Common \\
\hline 75 & Branded Yamfly & Yasoda tripunctata Hewitson, 1863 & Schedule II & Common \\
\hline 76 & Scarse-shot Silverline & Aphnaeus elima Moore, 1877 & & Seen at tea gardens of Panbari \\
\hline 77 & Elwes' Silverline & Spindasis elwesi Evans, 1925 & Schedule I & Seen few times at Panbari \\
\hline 78 & Long-banded Silverline & Aphnaeus lohita himalayanus Moore, 1884 & Schedule II & Not rare, seen everywhere \\
\hline 79 & Club Silverline & Aphnaeus syama Horsfield, 1829 & & Seen at Dollamora \\
\hline 80 & Double-tufted Royal & Dacalana vidura pencilligera De Nicéville, 1890 & & Seen once at Dollamora \\
\hline 81 & White-banded Royal & Dacalana cotys Hewitson, 1865 & & Seen a few times by Bitupon Borua near Kohora \\
\hline 82 & Blue Royal & Ancema carmentalis De Nicéville, 1892 & & Seen only once at Panbari \\
\hline 83 & Silver Royal & Ancema blanka de Nicéville, 1885 & Schedule II & $\begin{array}{l}\text { Seen in Numaligarh by me and in Kohora by } \\
\text { Bitupon Borua }\end{array}$ \\
\hline 84 & Broadtail Royal & Creon cleobis Godart, 1824 & & Sighted by Bitupon Borua at Kohora \\
\hline 85 & Banded Royal & Rachana jalindra indra Moore, 1883 & Schedule II & Sighted in woodlands of Bokakhat and Panbari \\
\hline
\end{tabular}




\begin{tabular}{|c|c|c|c|c|}
\hline & Common name & Scientific name & WLPA 1972 & Comments \\
\hline 86 & Mandarin Blue & Charana mandarinus Hewitson, 1863 & & Sighted in woodlands of Bokakhat \\
\hline 87 & Common Imperial & Cheritra freja Fabricius, 1793 & & Seen in the hill streams of Panbari \\
\hline 88 & Blue Imperial & Ticherra acte Moore, 1857 & & Seen in the hill streams of Panbari \\
\hline 89 & Common Onyx & Horaga onyx onyx Moore, 1857 & Schedule II & $\begin{array}{l}\text { Male seen twice in winter at Panbari and a female } \\
\text { seen once }\end{array}$ \\
\hline 90 & Common Tinsel & Catapoecilma elegans Druce, 1873 & & One seen in Panbari \\
\hline 91 & Orchid Tit & Chliaria othona Hewitson, 1865 & Schedule I & Common in the streams \\
\hline 92 & Common Tit & Hypolycaena erylus Godart, 1823 & & Found everywhere \\
\hline 93 & Fluffy Tit & Zeltus etolus Fabricius, 1787 & & Seen many times in Panbari \\
\hline 94 & Green Flash & Artipe eryx Linnaeus, 1771 & Schedule II & $\begin{array}{l}\text { Seen a few times at Panbari and once at } \\
\text { Numaligarh }\end{array}$ \\
\hline 95 & Cachar Flash & Artipe skinneri De Nicéville, 1887 & & Seen once at Dollamora \\
\hline 96 & Cornelians & Deudorix epijarbas amatius Fruhstorfer, 1912 & & Not rare in Panbari \\
\hline 97 & Indigo Flash & Rapala varuna orseis Hewitson, 1863 & Schedule II & Seen many times at Panbari \\
\hline 98 & Common Guava Blue & Virachola isocrates Fabricius, 1793 & & Seen once by Gaurab Nandi Das from Bokakhat \\
\hline 99 & Large Guava Blue & Virachola perse perse Hewitson, 1863 & & Seen once at Panbari in winter in forest edge \\
\hline 100 & Malayan Red Flash & Rapala damona Swinhoe, 1890 & & $\begin{array}{l}\text { Common at Panbari, Dollmaora and Bokakhat in } \\
\text { degraded patches }\end{array}$ \\
\hline 101 & Suffused Flash & Rapala suffusa Moore, 1878 & & Seen once at Panbari \\
\hline 102 & Brilliant Flash & Rapala rhoecus de Nicéville, 1895 & & Common \\
\hline 103 & Scarse Slate Flash & Rapala scintilla de Nicéville, 1890 & Schedule II & Common \\
\hline 104 & Slate Flash & Rapala manea schistacea Moore, 1879 & & Common \\
\hline 105 & Copper Flash & Vadebra pheritimus petosiris Hewitson, 1863 & & Common \\
\hline 106 & Scarlet Flash & Rapala dieneces Hewitson, 1878 & & Not rare in Panbari \\
\hline 107 & Narrow Spark & Sinthusa nasaka amba Kirby, 1878 & Schedule II & Common \\
\hline 107 & Broad Spark & Sinthusa chandara grotei Moore, 1884 & & Seen a few times at Dollamora \\
\hline 107 & Plane & Bindahara phocides Fabricius, 1793 & Schedule II & Not rare in Panbari \\
\hline 110 & Witch & Araotes lapithis Moore, 1857 & Schedule II & $\begin{array}{l}\text { Seen few times at Panbari, commonly seen in a } \\
\text { patche of Dollamora. }\end{array}$ \\
\hline 111 & Apefly & Spalgis epius Westwood, 1851 & & Not rare, also occurs in out side forest \\
\hline 112 & Great Darkie & Allotinus drumila Moore, 1865 & & $\begin{array}{l}\text { The identity of th species is not confirmed as the } \\
\text { specimen was quite worn out. Could also be a } \\
\text { Logania distanti. One sighted by Raju Kasambe in } \\
\text { December } 2015 \text {. }\end{array}$ \\
\hline 113 & Punchinello & Zemeros flegyas indicus Fruhstorfer, 1898 & & Common \\
\hline 114 & Plum Judy & Abisara echerius prunosa Moore, 1897 & & Common \\
\hline 115 & Double-banded Judy & Abisara bifasciata suffusa Moore, 1882 & & One seen on Panbari by Bitupon Borua \\
\hline 116 & Tailed Judy & Abisara neophron Hewitson, 1860 & & Seen in Dollamora and Kohora \\
\hline
\end{tabular}

rapid deforestation. Panbari Reserve is one of the last remaining natural forest tracts left in the area, protected under KNP. There is not much woodland left in the area and the species reported in the area shows the importance of woodlands in an area where conservation priority is given to the protection of mega fauna that exists in the grasslands of KNP. There should have been more emphasis on the conservation of woodlands in the area but unfortunately the area has lost most of the woodlands within a span of 60 years or so. Even now there are places like the Dollamora proposed Reserve Forest, which should have been upgraded to Reserve Forest for better protection, but no step has been taken till date to save the area and as a result continuous exploitation of the forest for fuel wood continues unabated. Sighting of extremely rare Artipe skinneri from unprotected Dollamora shows the importance of the area. But, unfortunately conservation 


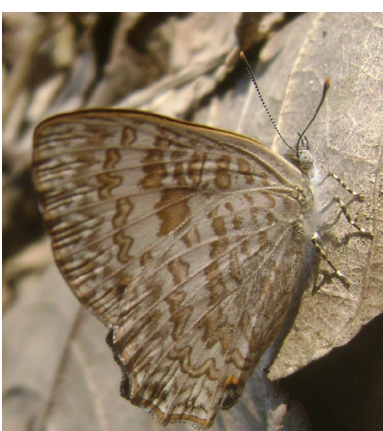

Image 3. Blue Gem Poritio erycinoides elsiei

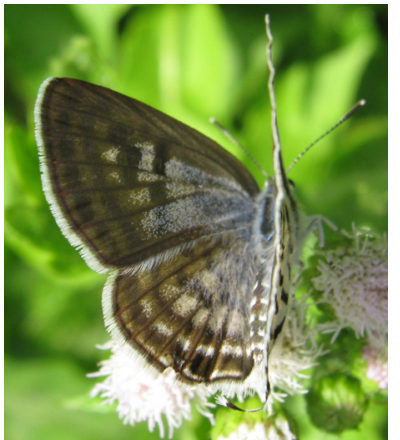

Image 7. Pointed Pierrot Tarucus theophrastus indica, male

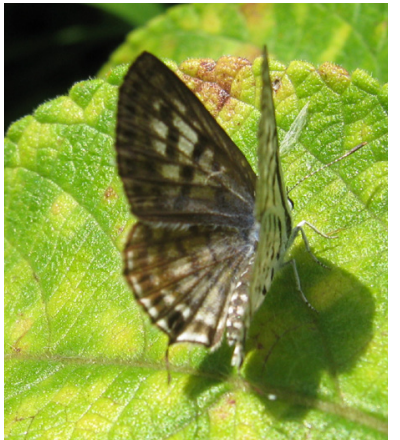

Image 11. Tarucus sp.

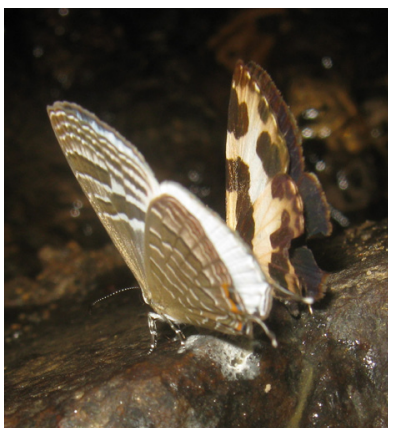

Image 15. Common Cerulean, Jamides celeno (Kaziranga)

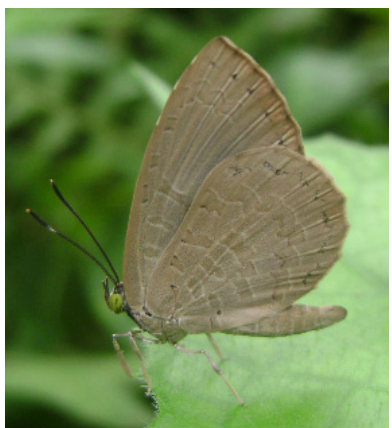

Image 4. Common Brownie Miletus chinensis assamensis

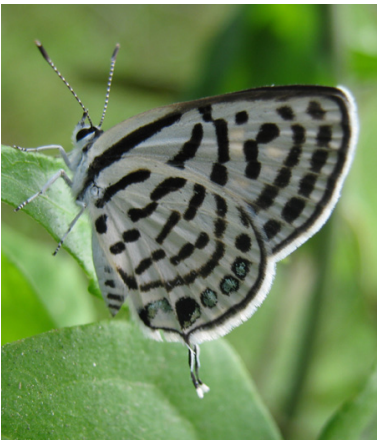

Image 8. Pointed Pierrot Tarucus theophrastus indica, male

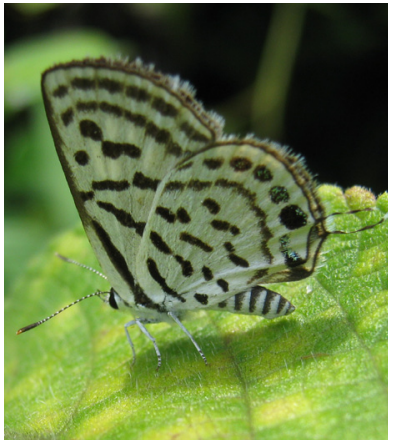

Image 12. Tarucus sp.

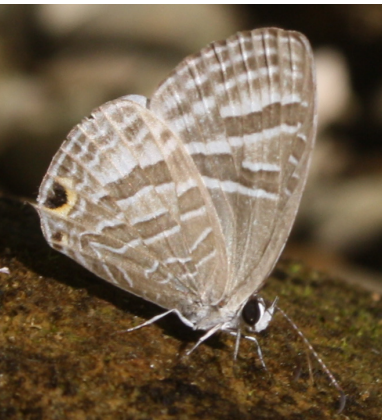

Image 16. White Cerulean, Jamides celodus pura (Cachar Hills)

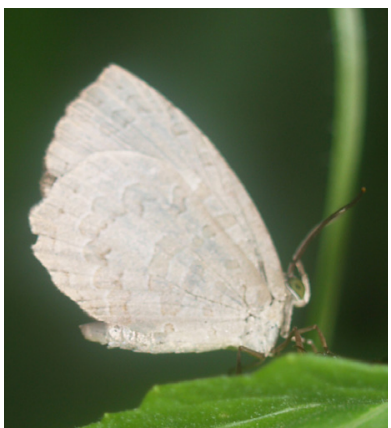

Image 5. Common Brownie Miletus boisduvali??

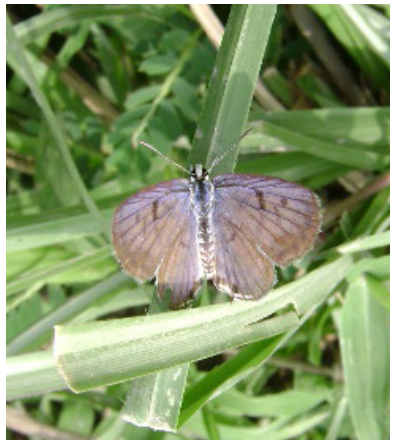

Image 9. Pointed Pierrot Tarucus theophrastus indica, female

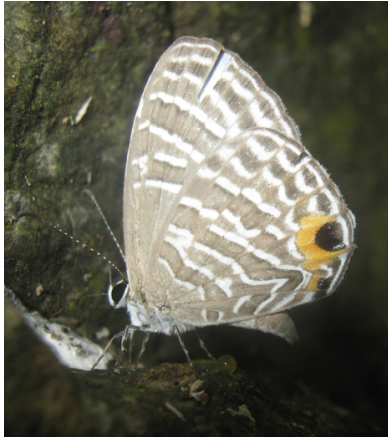

Image 13. White Cerulean Jamides cleodus pura (Kaziranga)

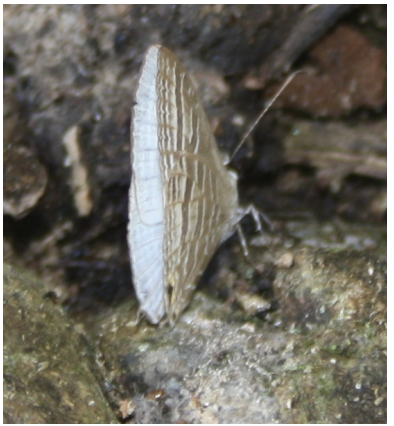

Image 17. White Cerulean Jamides cleodus pura (Cachar Hills)

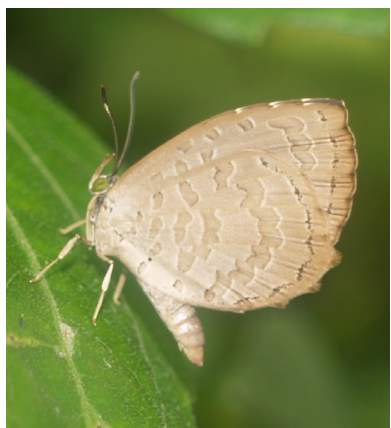

Image 6. Squareband Brownie Miletus nymphis porus

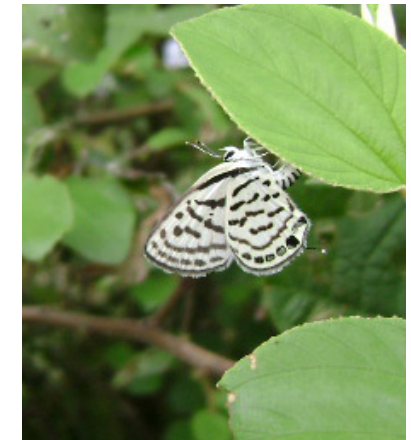

Image 10. Pointed Pierrot Tarucus theophrastus indica, female

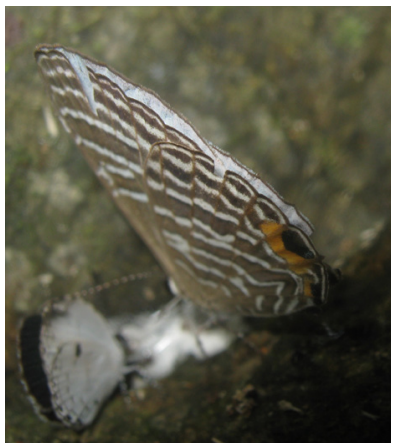

Image 14. White Cerulean Jamides cleodus pura (Kaziranga) upperside

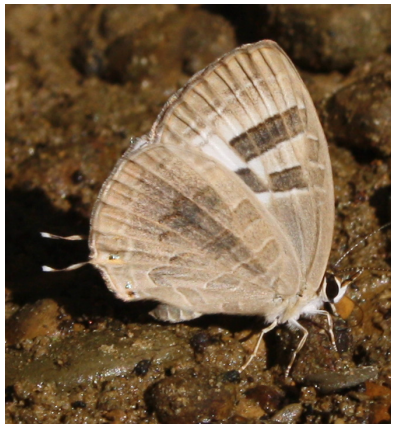

Image 18. Common Cerulean Jamides celeno (Cachar Hills) 


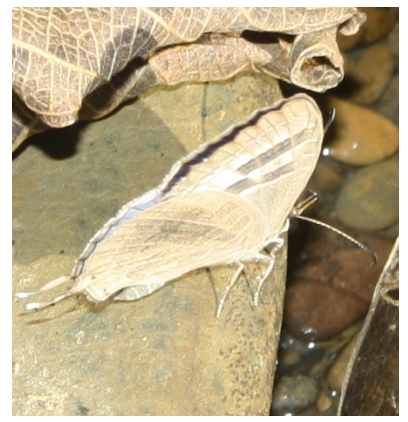

Image 19. Common Cerulean Jamides celeno (Cachar Hills)

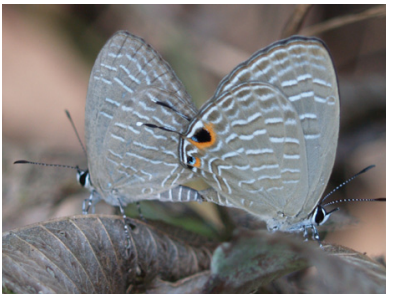

Image 23. Royal Cerulean Jamides caerulea

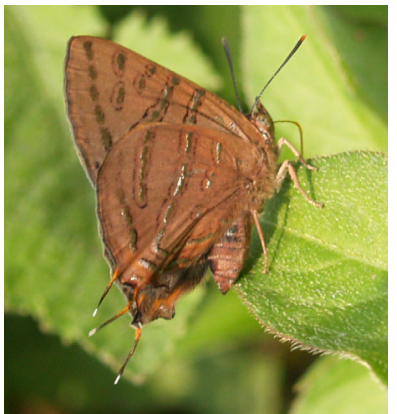

Image 27. Scarce Shot Silverline Aphnaeus elima

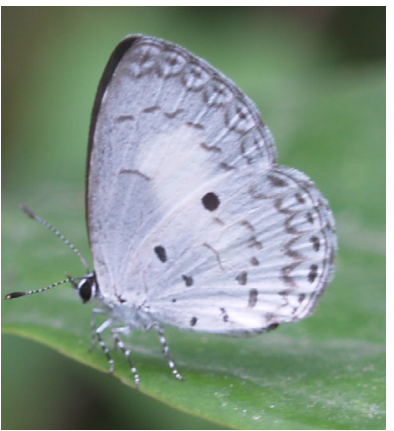

Image 30. Hill Hedge Blue Celastrina agriolus sikkima

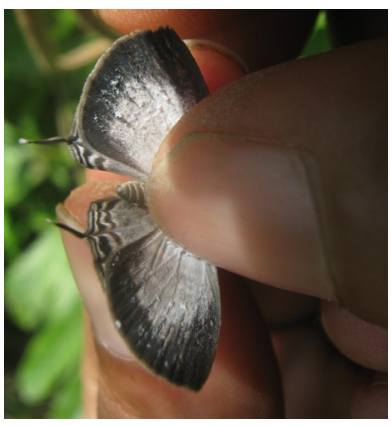

Image 20. Common Cerulean Jamides celeno (Kaziranga) female

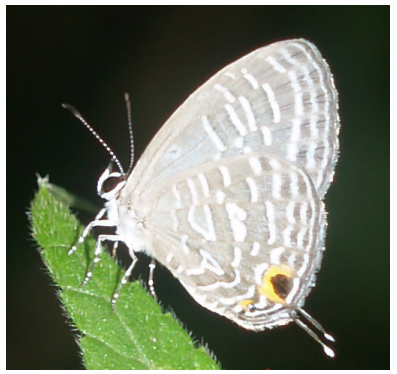

Image 24. Glistening Cerulean Lampides kankena

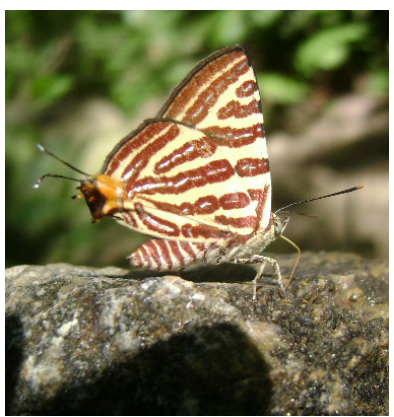

Image 28. Long-banded Silverline Aphnaeus lohita himalayanus

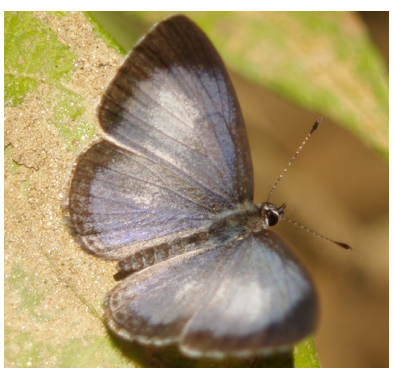

Image 32.White-banded Hedge Blue Lycaenopsis transpectus, male

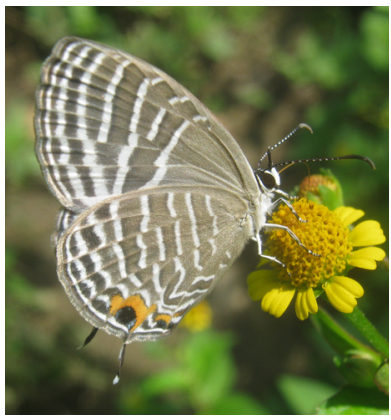

Image 21. Common Cerulean Jamides celeno (Kaziranga) female

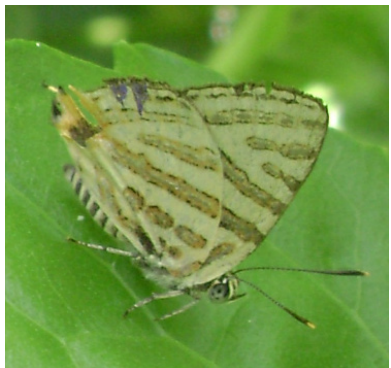

Image 25. Elwes Silverline Spindasis elwesi

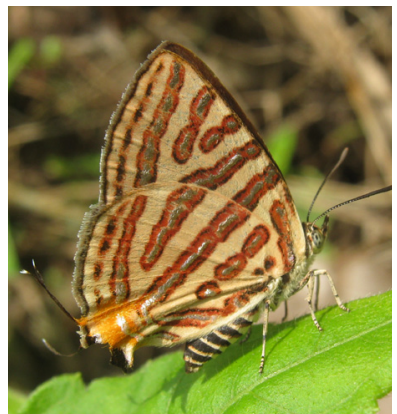

Image 29. Club Silverline, Aphnaeus syama

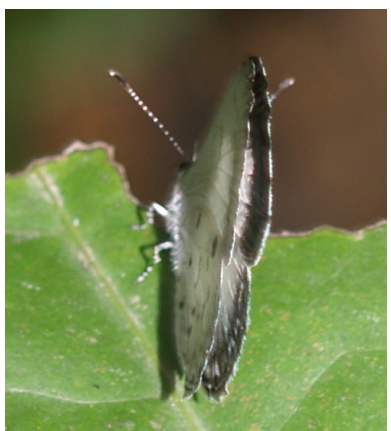

Image 33. White-banded Hedge Blue Lycaenopsis transpectus, female

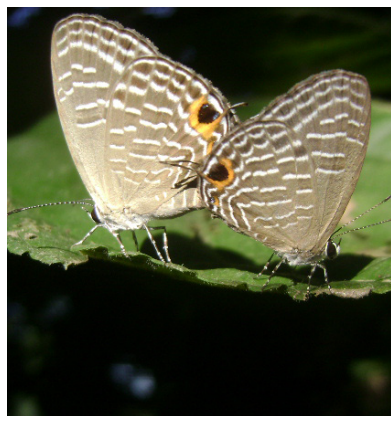

Image 22. Metallic Cerulean Jamides alecto

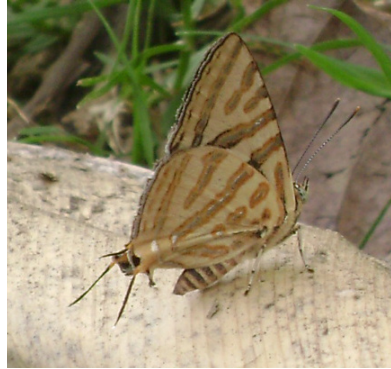

Image 26. Elwes Silverline Spindasis elwesi

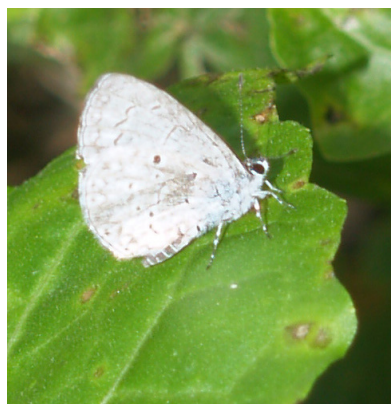

Image 30. Hill Hedge Blue Celastrina agriolus sikkima

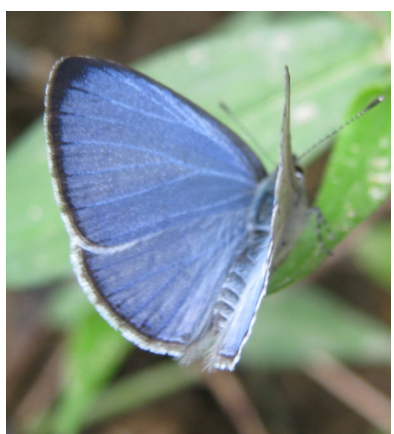

Image 34. Plain Hedge Blue Celastrina lavendularis limbata 


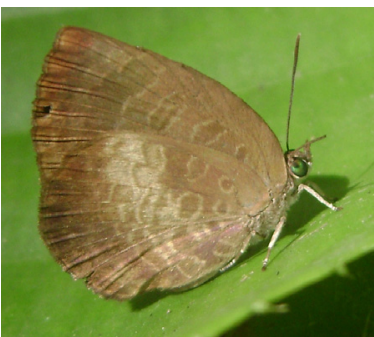

Image 35. Yellow-disc Tailless Oakblue Arhopala perimuta

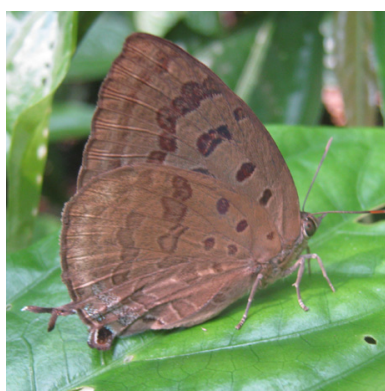

Image 39. Sylhet Oakblue Arhopala silhetensis

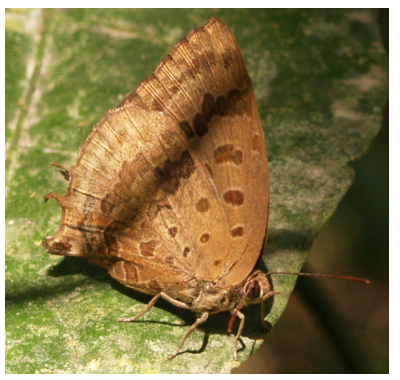

Image 43. Arhopala sp.

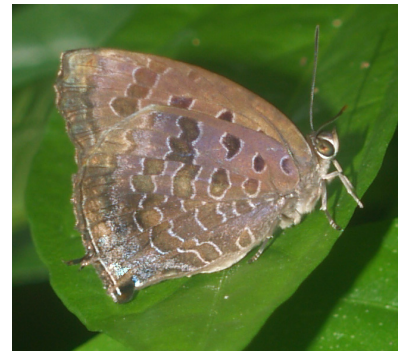

Image 47. Powdered Oakblue Arhopala bazalus teesta, female

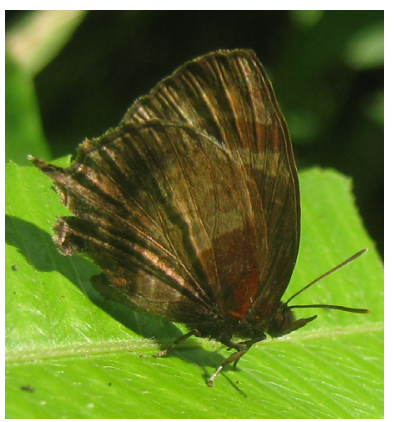

Image 36. Plain Plushblue Flos apidanus ahamus

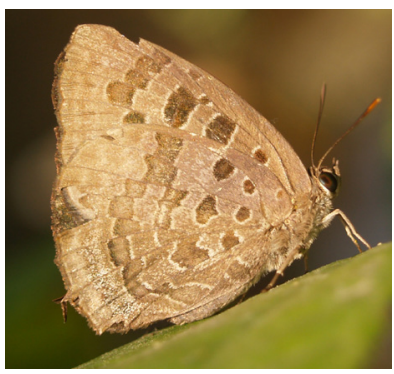

Image 40. Green Oakblue sp. Arhopala hellenore hellenore

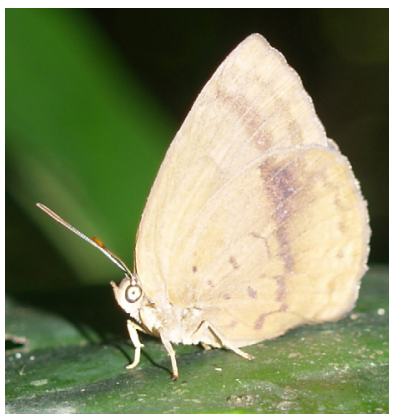

Image 44. Spotless Oakblue Arhopala fulla ignara

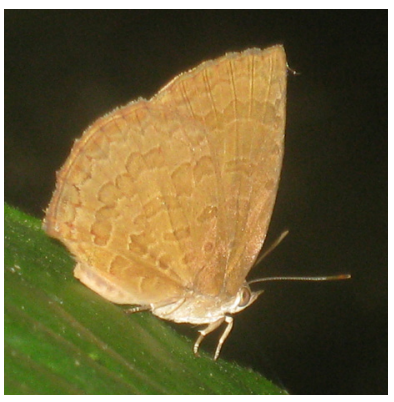

Image 48. Hooked Oakblue Arhopala paramuta

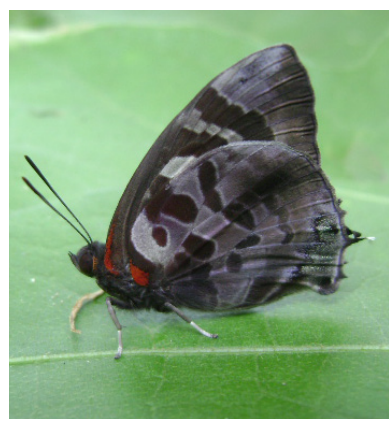

Image 37. Bifid Plushblue Flos diardi diardi

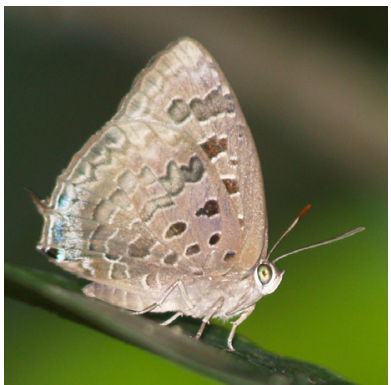

Image 41. Peacock Oakblue Arhopala horsfieldii eurysthenes

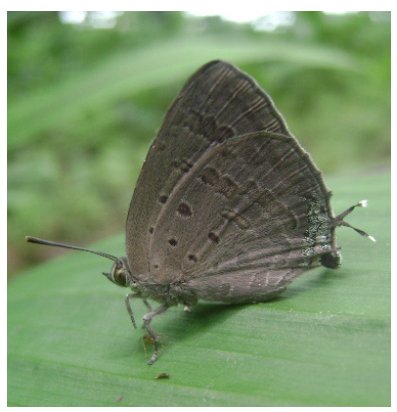

Image 45. Silky Oakblue Arhopala alax

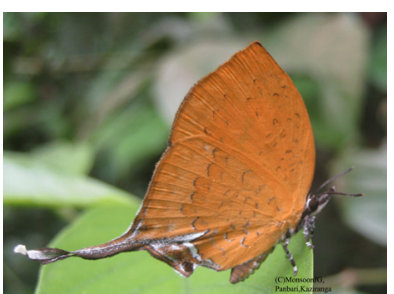

Image 49. Branded Yamfly Yasoda tripunctata

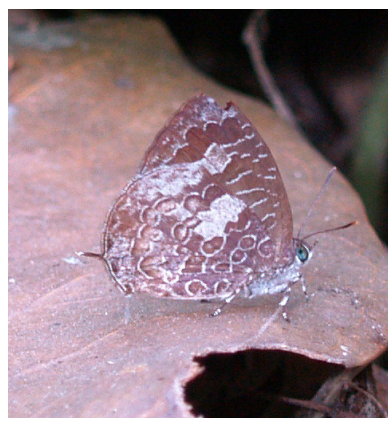

Image 38. Malayan Bushblue Arhopala ammonides elira

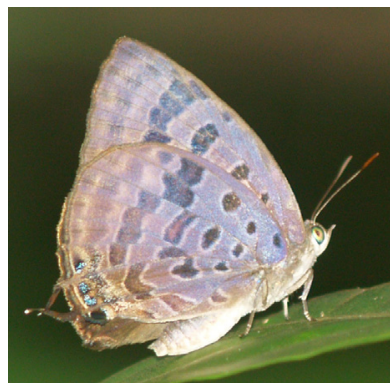

Image 42. Vinous Oakblue Arhopala athada apha

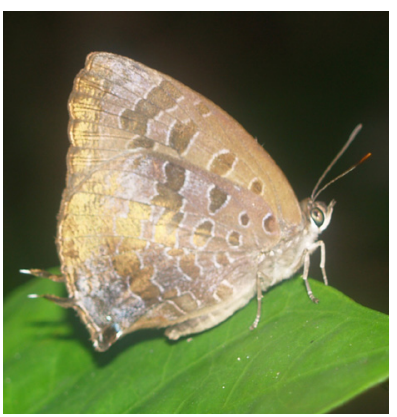

Image 46. Powdered Oakblue Arhopala bazalus teesta, male

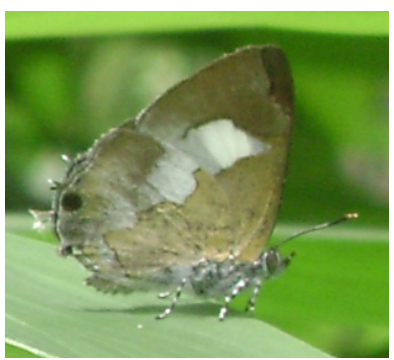

Image 50. Common Onyx Horaga onyx onyx 


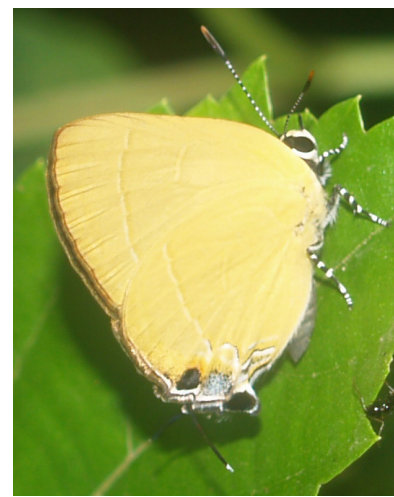

Image 51. Suffused Flash Rapala suffusa

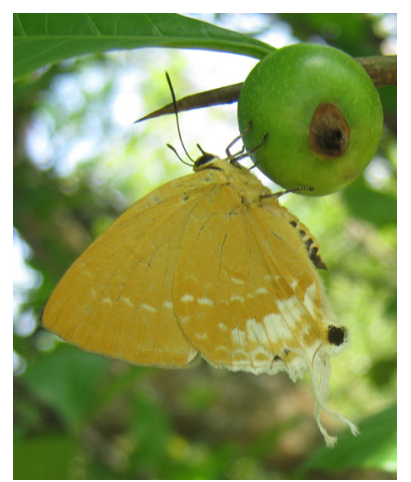

Image 55. Cachar Flash Artipe skinneri

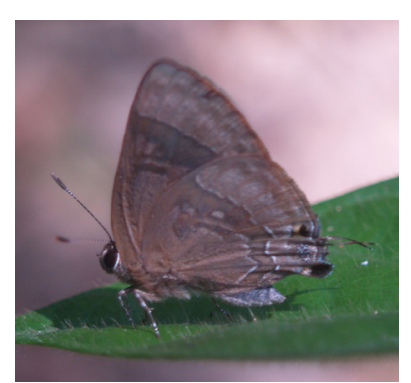

Image 59. Indigo Flash

Rapala varuna orseis

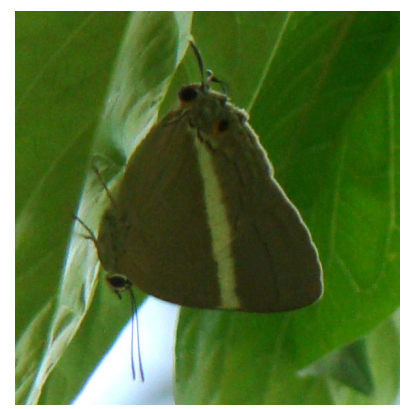

Image 63. Double tufted Royal Dacalana vidura pencilligera

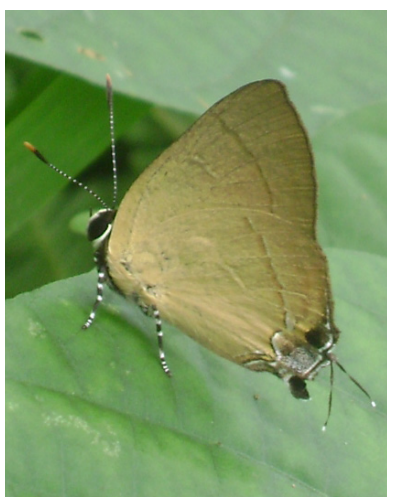

Image 52. Scarlet Flash

Rapala dieneces

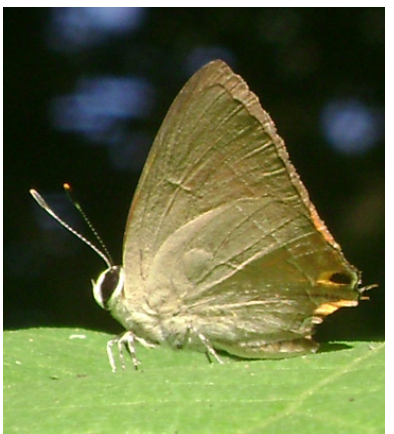

Image 56. Malayan Red Flash Rapala damona, male

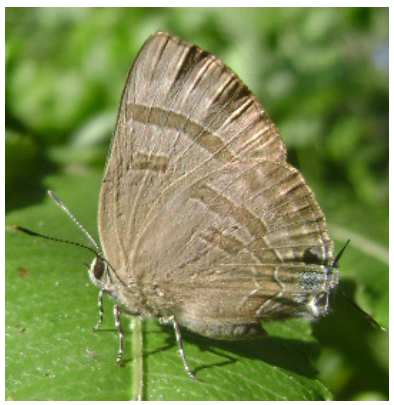

Image 60. Indigo Flash Rapala varuna orseis

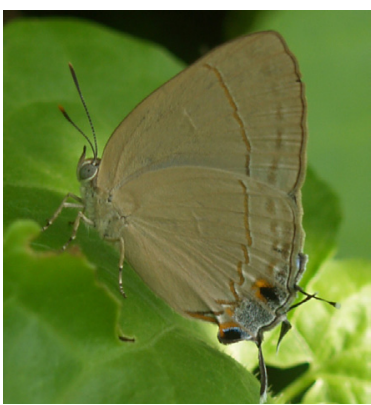

Image 64.Blue Royal Ancema carmentalis

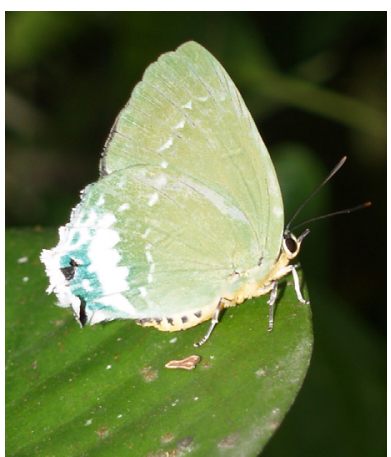

Image 53. Green Flash Artipe eryx, female

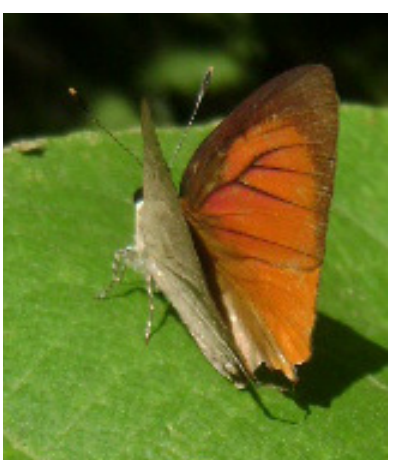

Image 57. Malayan Red Flash Rapala damona, male, UP

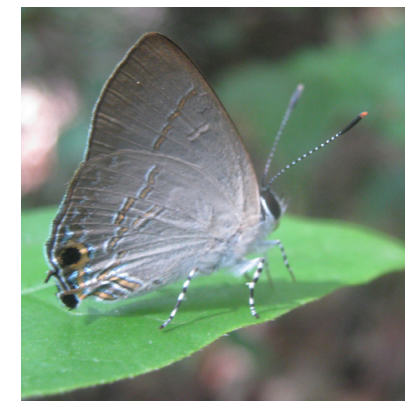

Image 61. Narrow Spark Sinthusa nasaka amba

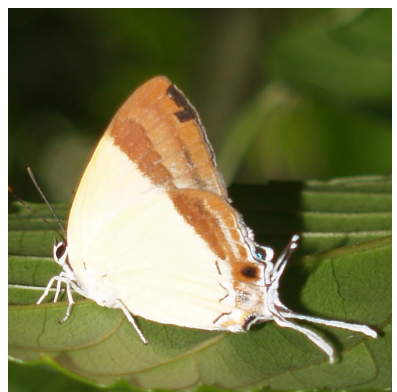

Image 65. Mandarin Blue Charana mandarinus

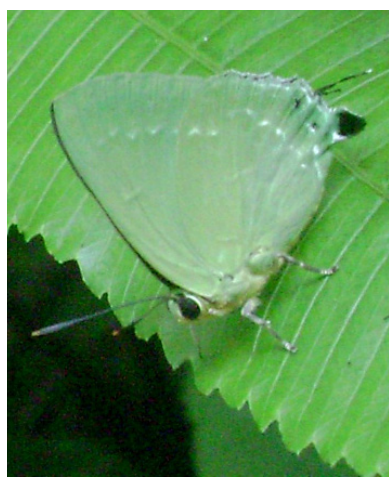

Image 54. Green Flash Artipe eryx, male

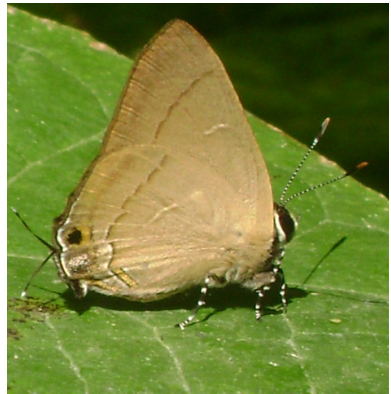

Image 58. Malayan Red Flash Rapala damona, female

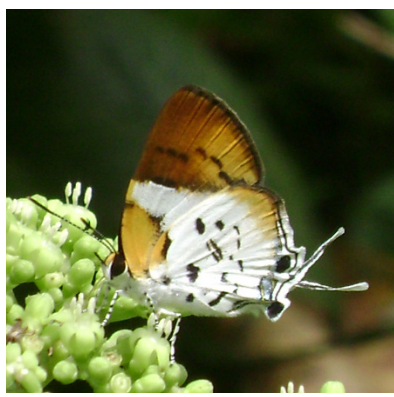

Image 62. Witch Araotes lapithis

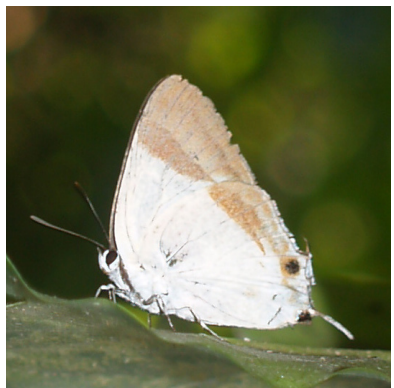

Image 66. Banded Royal Charana jalindra indra 


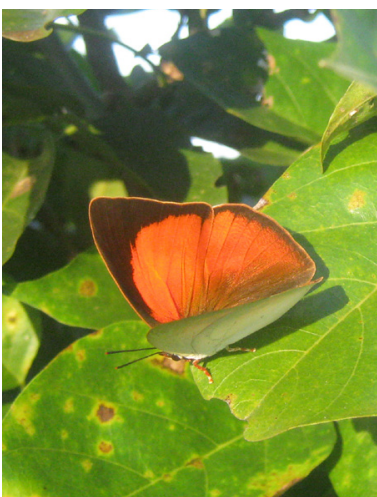

Image 67. Burmese Sunbeam Curetis saronis gloriosa, male

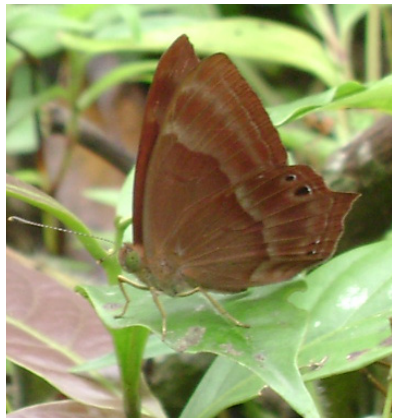

Image 71. Plum Judy Abisara echerius prunosa

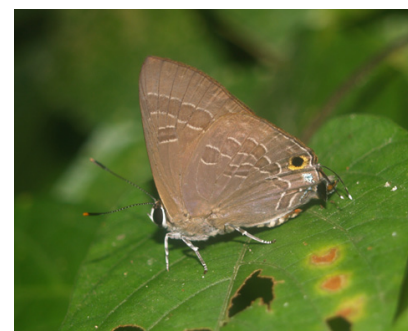

Image 75. Cornelian Deudorix epijarbas amatius

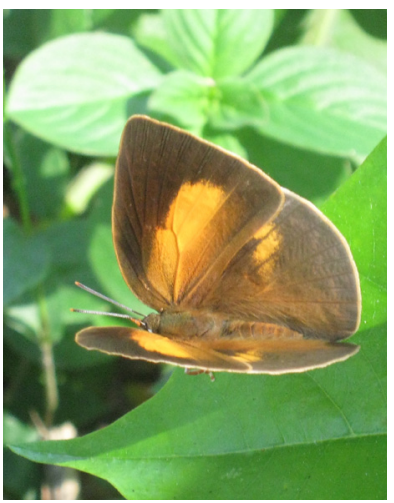

Image 68. Burmese Sunbeam Curetis saronis gloriosa, female

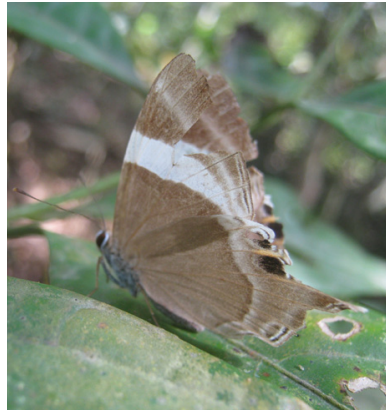

Image 72. Tailed Judy Abisara neophron

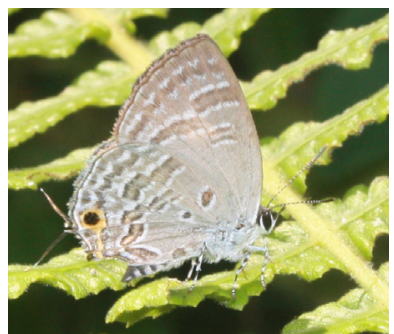

Image 76. Broad Spark Sinthusa chandara grotei

priority of woodland has been neglected in KazirangaKarbi Anglong Landscape and hence only a very small fragment of forest still remains natural.

\section{REFERENCES}

Cantlie, K. (1952). More butterflies of the Khasi and Jaintia Hills, Assam. Journal of the Bombay Natural History Society 51: 42-60. Evans, W.H. (1932). The Identification of Indian Butterflies - $2^{\text {nd }}$ Edition. Bombay Natural History Society, Mumbai, 454pp.

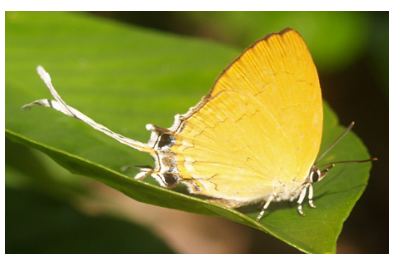

Image 69. Blue Imperial Ticherra acte

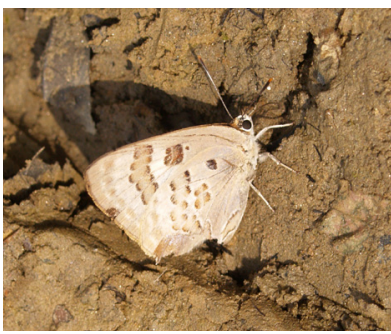

Image 73. Large Guava Blue Virachola perse perse

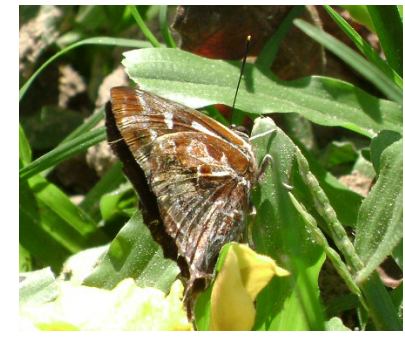

Image 74. Silverstreak Blue Iraota timoleon
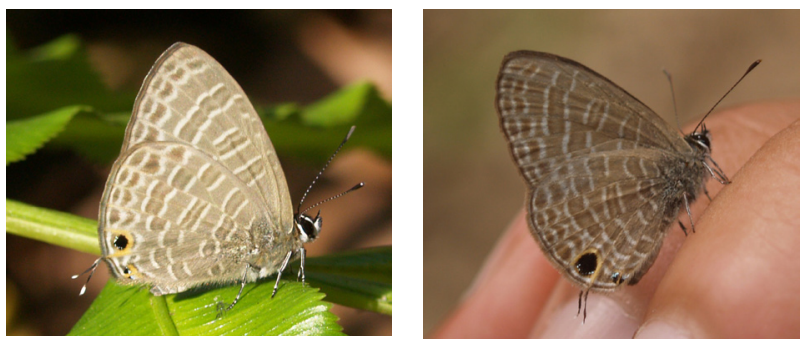

Image 77. Transparent 6 Lineblue Nacaduba kurava

Image 78. Opaque 6 Lineblue Nacaduba beroe gythion

Evans, W.H. (1957). A revision of the Arhopala group of oriental Lycaenidae (Lepidoptera: Rhopalocera). Bulletin of British Museum (Natural History) Entomology 5(1): 85-141.

Gogoi, M.J. (2013). Notes on some skipper butterflies (Lepidoptera: Hesperiidae) from Panbari Forest and its adjoining areas, KazirangaKarbi Anglong, upper Assam, India. Journal of Threatened Taxa 5(13): 4759-4768; http://dx.doi.org/10.11609/JoTT.03340.4759-68

Haribal, M. (1992). The Butterflies of Sikkim Himalaya. Sikkim Nature Conservation Foundation, Sikkim, India, 217pp.

Kehimkar, I. (2008). The Book of Indian Butterflies. Bombay Natural History Society and Oxford University Press, Mumbai, India, 497pp.

Norman, T. (1953). Notes on the Lepidoptera of Assam-II. Some additions to Assam list and other notes. Journal of the Bombay Natural History Society 51: 515-517

Tytler, H.C. (1915b). Notes on some new and interesting butterflies from Manipur and the Naga Hills. Part III. Journal of the Bombay Natural History Society 24: 119-155.

Wood-Mason, J. \& L. De Nice'ville (1886). List of the Lepidoptera Insects Collected in Cachar by Mr. Wood-Mason: Part II - Rhopalocera. Journal of the Asiatic Society of Bengal 55(4): 53. 